\title{
The Effects of Entrepreneurial Orientation on Business Performance
}

\author{
Dr Simon Radipere \\ Department of Business Management, \\ University of South Africa, South Africa \\ radipns@unisa.ac.za
}

Doi:10.5901/mjss.2014.v5n16p141

\begin{abstract}
Entrepreneurship scholars have attempted to explain performance by investigating the relationship between entrepreneurial orientation and firm performance. Therefore, the study will look at how entrepreneurial orientation impact on business performance. Questionnaire was used to collect data from 500 SMMEs owners. The findings from the survey among 500 SMME owners were modelled through a categorical regression model with business performance as dependent variable. The level of significance of the eight variables out of twelve variables suggests that entrepreneurial orientation be classified as the strongest predictor of business performance. The ability to adjust one's business model to adapt to changed economic circumstances is an important thing as it dictates performance in increasingly competitive economic environment.
\end{abstract}

Keywords: entrepreneurial orientation; business performance

\section{Introduction}

As the pace of change continues to accelerate globally, the success of community enterprises depends on the innovation of entrepreneurs. Yet the Global Entrepreneurship Monitor (GEM, 2011) reported South Africa as performing low (9.1\%) and GEM (2012) reported 7.3\% in entrepreneurship, with total entrepreneurial activity (TEA) below the average of comparable economies around the world. This remains a concern and feeds the debate around the factors that impact on entrepreneurial performance.

South Africa's low ranking in global competitiveness is a source of national concern. This means that South Africa has the smallest proportion of entrepreneurs compared with other developing countries. This is a problem in a country where entrepreneurial ventures account for one-third of total employment. The unemployment rate in post-apartheid South Africa remains extremely high, with unemployment especially among black South Africans worsening since 1994 (GEM, 2011). With the increase in unemployment, which is in part due to the apartheid legacy, current government policies are increasingly being questioned. The GEM (2011) reported South Africa as ranking $110^{\text {th }}$ out of 135 countries in terms of the unemployment rate.

It is therefore necessary to understand how the entrepreneurial start-up factors (motivation, culture, self-efficacy, intention and entrepreneurial orientation) affect business performance - in other words, there is needs to find out to what extent the entrepreneurial start-up factors affect performance of business. Therefore, the study will only look at how entrepreneurial orientation as one of start-up factors impact on business performance.

Entrepreneurship scholars have attempted to explain performance by investigating the relationship between entrepreneurial orientation and firm performance (Lumpkin \& Dess, 2001:436). Entrepreneurial orientation refers to a firm's strategic orientation, acquiring specific entrepreneurial aspects of decision-making styles, practices and methods. Other studies have found that entrepreneurial orientation enables small firms or new ventures to perform better than their competitors and enhances firm performance (Wiklund \& Shepherd, 2005). Entrepreneurial orientation has become a central concept in the domain of entrepreneurship that has received a substantial amount of theoretical and empirical attention (Lumpkin \& Dess, 2001).

This study adopts Lumpkin and Dess's (2001) definition of entrepreneurial orientation as the strategy-making processes that provide organisations with a basis for entrepreneurial decisions and actions. The entrepreneur is the decision-maker in the business and he or she undertakes risk. Lumpkin and Dess (2001) further indicate that entrepreneurial orientation is a key ingredient for organisational success and it has been found to lead to increased performance. Strategy-making is an organisation-wide phenomenon that incorporates planning, analysis, decisionmaking and other aspects of an organisation's culture, value system and mission. Wiklund and Shepherd (2005) argue that entrepreneurial orientation leads to higher performance or that businesses that adopt a strong entrepreneurial 
orientation perform better than firms that do not adopt an entrepreneurial orientation.

Entrepreneurial orientation is demonstrated by the extent to which management inclined to take business-related risks to favour changes and innovation, in order to obtain a competitive advantage for the business (Andendorff, 2004). Recent research suggests that there are three dimensions of entrepreneurial orientation that may vary independently from one another. They are: risk-taking, innovation and proactiveness (Lumpkin \& Dess, 2001). Rwigema, Venter \& Urban (2008) indicate that innovativeness is at the centre of entrepreneurship and is the fundamental endeavour of an entrepreneurial organisation to develop new products or invent new processes. Risk-taking is associated with the willingness of the entrepreneur to take calculated business-related risks. Proactiveness consists of autonomy and competitive aggressiveness. Autonomy refers to the actions undertaken by individuals or teams intended to establish a new business concept or idea (Rwigema et al, 2008) and further highlights that competitive aggressiveness refers to a response to threats that already exist in the marketplace. Entrepreneurial orientation has its roots in the strategy-making process literature (Rauch, Wiklund, Lumpkin \& Frese, 2009). Strategy-making is an organisational phenomenon that incorporates planning, analysis, decision-making and many aspects of an organisation's culture, value system and mission. Firm entrepreneurial orientation therefore represents policies and practices that provide a basis for entrepreneurial decisions and actions (Rauch et al, 2009).

According to literature, factors that affect a person's decision to start a business include culture, motivation, entrepreneurial orientation, entrepreneurial intention and self-efficacy. Research assumes that these factors impact on business performance. This study aimed to examine the effect of entrepreneurial orientation on business performance.

This paper is structured in the following manner: section 1 presented the research background and aim of the study. The next section, 2 presents literature review on entrepreneurial orientation and business performance. The section further elaborates the constructs used in this study and outlines proposed hypotheses. Section 3 presents the research methodology and finally, section 4 concludes the paper with a discussion of the findings and implications for practitioners.

\section{Literature Review}

\subsection{A firm's entrepreneurial orientation and performance}

Businesses with entrepreneurial orientation have the capability to discover and exploit new market opportunities (Wiklund \& Sheperd, 2003). Other research has employed a variety of financial measures like cash flow, return on assets and return on equity to assess firm performance. Some studies suggest a combination of financial and non-financial measures offers more comprehensive evaluation on a firm's performance (Li et al 2009). Subjective non-financial measures include indicators such as perceived market share, perceived sales growth, customer satisfaction, loyalty and brand equity (Li et al, 2009). Murphy, Trailer and Hill (1996) examined 51 published entrepreneurial studies using performance as the dependent variable and found that the most commonly considered dimensions of performance were related to efficiency, growth and profit. Efficiency comprises some financial measures like return on investment and return on equity; growth focuses on increase in sales, employees or market share; and profit includes return on sales and net profit margin.

Lumpkin and Dess (2001) indicate that the dimensions of entrepreneurial orientation can lead to market growth. The innovativeness dimension of entrepreneurial orientation reflects the tendency to engage in and support the novelty to create and introduce new products, services or technology. The risk-taking orientation indicates a willingness to engage resources in strategies or projects where the outcome may be highly uncertain. Proactiveness refers to a firm's response to promising market opportunities. Competitive aggressiveness involves the propensity to directly and intensely challenge its competitors. Autonomy describes the authority and independence given to an individual or team within the firm to develop business concepts and visions, and to carry them through to completion. If new businesses have more aptitude for innovativeness, risk taking, proactiveness, competitive aggressiveness and autonomy, they will gain greater competitive advantage and accomplish higher firm performance. An effective entrepreneurial orientation may be a good predictor of a firm's performance. The study adopts Lumpkin and Dess's (2001) approach of using five (instead of three) dimensions of entrepreneurial orientation. It is an acceptable expanded definition of entrepreneurship orientation (Antoncic and Hisrich 2003).

Cooper and Gascon (1992) highlight individual factors influencing performance as experience, education, occupation of parents, gender, race, age and the entrepreneur's goals. Studies of individual factors influencing performance are prevalent, although the majority of these were carried out in the USA, Canada and the United Kingdom.

We used business performance as our dependent variable because of its importance to organisations, individual 
and society. Business performance is also an outcome that all entrepreneurs must address. We selected entrepreneurial orientation as an independent variable since it has theoretical relationship with business performance. Entrepreneurial orientation has little attention in the entrepreneurship literature although is found to be an important determinant of many life and outcomes (Bandura, 1997). For our firm level behavioural variable, we looked at entrepreneurial orientation. Entrepreneurship literature revealed that there is little theoretical and empirical work that has been offered to explain the mechanism through which entrepreneurial orientation affect business performance.

The importance of entrepreneurial orientation and its influence on business performance have been highlighted in theoretical discussions and empirical research. Entrepreneurial orientation at theoretical level is said to have positive effect on performance because firms with this strategic posture have advantage and are able to capitalise on emerging opportunities (Wiklund \& Sheperd, 2003). Past studies at empirical level have shown a positive relationship between entrepreneurial orientation and firm performance, e.g. a longitudinal study have found that entrepreneurial orientation to have long term effect on growth and financial performance of small businesses (Wiklund \& Sheperd, 2003).

In this study we propose that entrepreneurial orientation may be a useful process variable to explain effects on business performance. Firms led by entrepreneurs who engage in certain behavioural traits like internal locus of control, are likely to adopt entrepreneurial orientation. Therefore the study suggest that: $\mathrm{H}_{0} 1$ : There is a significant positive relationship exists between entrepreneurial orientation and business performance ( $\mathrm{H}_{0} 1 \mathrm{a}$ : my business income; $\mathrm{H}_{0} 1 \mathrm{~b}$-my business profit; $\mathrm{H}_{0} 1 \mathrm{c}$ - my market share; $\mathrm{H}_{0} 1 \mathrm{~d}$ - my return on investment; $\mathrm{H}_{0} 1 \mathrm{e}$ - number of employees; $\mathrm{H}_{0} 1 \mathrm{f}$ - product line).

\section{Methodology}

The population of the study is SMMEs (Small, Medium and Micro enterprises) in the retail sector of the Gauteng province of South Africa. The researcher uses the brabys.com populations of SMMEs in Gauteng since this organisation is reliable and is the leading registry of SMMEs in the country (GEM 2012). According to Brabys, the population size of SMMEs in the retail industry is 10000 . The study population was therefore based on 10000 SMMEs.

Probability sampling was used to ensure that each member of SMME population is given a known non-zero chance of selection. Simple random sampling was utilised to identify the respondents. According to Cooper and Schindler (2008:409), the sample size that is acceptable is $5 \%$ of the total population. Given this study's estimate of a population of 10000 , it means that the targeted sample was 500 respondents (that is, 10000 entrepreneurs $X 0.05=500$ respondents). A structured research instrument (a questionnaire) was used to collect data through self-administration interviews and out of the targeted sample, 466 responses were received which yielded a 93.2\% response rate.

\subsection{Measures}

The investigative questions concerned the following constructs:

\subsubsection{Entrepreneurial orientation}

This concept was based on Lumpkin and Dess (2001) who indicate that the dimensions of entrepreneurial orientation can lead to market growth.

Respondents were requested to rate the extent to which they agree with the statements on entrepreneurial orientation. A five-point Likert scale (strongly agree, agree, don't know, disagree and strongly disagree) was used for each of the sixteen questions that were asked. The 16 items were aimed at finding out the orientation of entrepreneurs.

The questions asked from this variable are based on the following statement: there is a strong emphasis on the marketing of tried and true products or services; one should try new ways of doing things; one should adopt from competitors new ways of doing business; one should try new lines of products or service; one should try changes in product lines that are mostly of a minor nature; one should try many new lines of product services; in dealing with competitors my business... typically responds to actions that competitors initiate; is seldom the first business to introduce new product/services, administrative techniques, operating technologies; typically initiates actions that competitors then respond to; is very often the first business to introduce new product/services, administrative techniques, operating technologies; is the one with strong tendency to follow the leader in introducing new product or ideas; have a strong tendency to be ahead of other competitors in introducing novel ideas or products; it is important to have a strong proclivity for low-risk projects (with normal and certain rates of return; it is important to have a strong proclivity for high-risk projects (with chances of very high returns); it is unimportant to have a strong proclivity for low-risk projects and it is unimportant to have a strong proclivity for high risk projects. 
The assumption was that there is a relationship between entrepreneurial orientation and business performance. The researcher therefore wanted to see if this was true and to find out which factors affect business positively and to what extent.

\subsubsection{Business performance}

Most researchers used growth as a proxy for business performance. Growth as a measure of business performance may be more accurate and accessible same as accounting measures of financial performance. We ascribe to the view that performance is multidimensional in nature and it is therefore advantageous to integrate different dimensions of performance in empirical studies. To capture different aspects of small business performance, we combined measures of financial performance and growth. List of independent variables used to quantify business performance are; my business income; my business profit; market share; return on investment; number of employees and product line. Respondents were requested to rate the extent to which they agree with the statements on business performance. A five-point Likert scale (strongly agree, agree, don't know, disagree and strongly disagree) was used for each of the six questions that were asked. The 6 items were aimed at finding out the performance of business.

The assumption was that there is a relationship between entrepreneurial orientation and business performance. The researcher therefore wanted to see if this was true and to find out which factors affect business positively and to what extent.

\subsubsection{Analysis}

The statistical analysis makes use of a categorical regression model to facilitate the investigation of causal relationship in the data. This model was preferred over other categorical association measures such as chi-square, Cromer's $V$ and Lamda, which would not allow the same level of analysis, especially with regard to causal relationships. Another reason of using categorical regression model derives from the usage of ordinal and nominal data in the model and also that the dependent variable is dichotomous. The dependent variable is defined as the performance of a business with six categories, namely my business income; my business profit; market share; return on investment; number of employees and product line. 0.814

The reliability for the construct "entrepreneurial orientation" is acceptable, with an overall Cronbach's alpha value of

\section{Results}

\subsection{My business income}

There is a significant positive relationship exists between entrepreneurial orientation and business performance $\left(\mathrm{H}_{0} 1 \mathrm{a}\right.$ : my business income).

The results from the analysis of variance are depicted in table 1 below. These show that the model variance (1.490) is considerably higher than the error variance (0.969), indicating that the different predictors separately and conjointly succeeded in predicting business performance significantly at $95 \%$ level of certainty.

Table 1: ANOVA: my business income

\begin{tabular}{|c|c|c|c|c|c|}
\hline & Sum of Squares & Df & Mean Square & F & Sig. \\
\hline Regression & 40.230 & 27 & 1.490 & 1.538 & .044 \\
Residual & 379.770 & 392 & .969 & & \\
Total & 420.000 & 419 & & & \\
\hline
\end{tabular}

The regression coefficients obtained by estimating the full model is presented in Table 2 below. Given that a total of 500 observations were used, the fairly large number of variables listed can be included in the regression to determine which ones are significant in determining business performance.

The standardised coefficients with regard to "my business income" in table below were found to present strong predictors of business performance. With regard to my business income, some of the variables are above 0.050 level of significance and can therefore be regarded as weak predictors of business performance. These include the following: 
there is a strong emphasis on the marketing of tried and true products or services; one should adopt from competitors new ways of doing business; one should try changes in product lines that are mostly of a minor nature; In dealing with competitors my business; is seldom the first business to introduce new product/services, administrative techniques, operating technologies; typically initiates actions that competitors then respond to; is the one with strong tendency to follow the leader in introducing new product or ideas; have a strong tendency to be ahead of other competitors in introducing novel ideas or products; it is important to have a strong proclivity for high-risk projects (with chances of very high returns); it is unimportant to have a strong proclivity for low-risk projects and it is unimportant to have a strong proclivity for high risk projects.

These factors do not relate strongly to entrepreneurial orientation to start a business and are not predictors of business performance under "my business income". The table shows some entrepreneurial orientation factor between $5 \%$ and $20 \%$ level of significance. Statistically, these factor (namely; It is important to have a strong proclivity for high-risk projects (with chances of very high returns) can be considered as of marginal significance. These can be tested further in another research project.

Table 2: Regression coefficients indicating the significance of entrepreneurial orientation variables to business performance (My business income)

\begin{tabular}{|c|c|c|c|c|c|}
\hline \multicolumn{6}{|l|}{ Coefficients } \\
\hline & \multicolumn{2}{|c|}{ Standardized Coefficients } & \multirow[b]{2}{*}{ Df } & \multirow[b]{2}{*}{$\mathrm{F}$} & \multirow[b]{2}{*}{ Sig. } \\
\hline & Beta & $\begin{array}{c}\text { Bootstrap } \\
\text { (1000) Estimate } \\
\text { of Std. Error }\end{array}$ & & & \\
\hline One should try new ways of doing things. & .187 & .059 & 2 & 11.080 & .000 \\
\hline One should adopt from competitors new ways of doing business. & .097 & .145 & 2 & .447 & .640 \\
\hline One should try new lines of products or service & .162 & .069 & 3 & 5.496 & .004 \\
\hline One should try many new lines of product services & .045 & .138 & 2 & 3.167 & .043 \\
\hline typically responds to actions that competitors initiate & .226 & .137 & 3 & 2.732 & .044 \\
\hline $\begin{array}{l}\text { is seldom the first business to introduce new product/services, administrative } \\
\text { techniques, operating technologies etc. }\end{array}$ & -.081 & .131 & 2 & .382 & .683 \\
\hline $\begin{array}{l}\text { is very often the first business to introduce new product/services, administrative } \\
\text { techniques, operating technologies }\end{array}$ & .165 & .078 & 2 & 4.414 & .013 \\
\hline $\begin{array}{l}\text { is the one with strong tendency to follow the leader in introducing new product or } \\
\text { ideas. }\end{array}$ & -.017 & .131 & 2 & .017 & .983 \\
\hline $\begin{array}{l}\text { It is important to have a strong proclivity for low-risk projects (with normal and } \\
\text { certain rates of return) }\end{array}$ & -.068 & .113 & 1 & .365 & .546 \\
\hline $\begin{array}{l}\text { It is important to have a strong proclivity for high-risk projects (with chances of very } \\
\text { high returns). }\end{array}$ & .188 & .113 & 3 & 2.641 & .049 \\
\hline It is unimportant to have a strong proclivity for low-risk projects & -.068 & .104 & 3 & .419 & .740 \\
\hline It is unimportant to have a strong proclivity for high risk projects & -.057 & .126 & 3 & .202 & .895 \\
\hline
\end{tabular}

Table 2 shows regression coefficient indicating the significance of entrepreneurial orientation variables to business performance.

With regard to business income, some of the variables are above 0.050 level of significance and can therefore be regarded as weak predictors of business performance but only six (is very often the first business to introduce new product; one should try new ways of doing things; one should try new ways of doing things; one should try many new lines of product services; typically responds to actions that competitors initiate; is very often the first business to introduce new; it is important to have a strong proclivity for high-risk projects), are predictors of business performance under "my business income" with significance level of $0.000 ; 0.004 ; 0.043 ; 0.044 ; 0.013$ and 0.049 . The hypothesis $\left(\mathrm{H}_{0} 1 \mathrm{a}\right)$ is accepted for these variables.

\subsection{My business profit}

There is a significant positive relationship exists between entrepreneurial orientation and business performance $\left(\mathrm{H}_{0} 1 \mathrm{a}\right.$ : my business profit).

With regard to "my business profit" most variables do not affect business performance. The significance level of 
most of the variables falls above the $0.05 \%$ level of significance. There are few strong predictors of business performance.

Table 3: ANOVA: my business profit

\begin{tabular}{|c|c|c|c|c|c|}
\hline & Sum of Squares & Df & Mean Square & $\mathrm{F}$ & Sig. \\
\hline Regression & 49.628 & 25 & 1.985 & 2.112 & .002 \\
Residual & 369.372 & 393 & .940 & & \\
Total & 419.000 & 418 & & & \\
\hline
\end{tabular}

The results from the analysis of variance are depicted in table 3 above. These show that the model variance (1.985) is considerably higher than the error variance $(0.940)$, indicating that the different predictors separately and conjointly succeeded in predicting business performance significantly at $95 \%$ level of certainty.

With regard to "my business profit", the majority of variables are above 0.050 level of significance and can therefore be regarded as weak predictors of business performance. This implies that these variables should not be considered for any improvement in business performance.

Table 4: Regression coefficients indicating the significance of entrepreneurial orientation variables to business performance (my business profit)

\section{Coefficients}

\begin{tabular}{|c|c|c|c|c|c|}
\hline & \multicolumn{2}{|c|}{ Standardized Coefficients } & \multirow[b]{2}{*}{ Df } & \multirow[b]{2}{*}{$\mathrm{F}$} & \multirow[b]{2}{*}{ Sig. } \\
\hline & Beta & $\begin{array}{l}\text { Bootstrap (1000) } \\
\text { Estimate of Std. Error }\end{array}$ & & & \\
\hline One should try new ways of doing things. & .187 & .159 & 2 & 11.80 . & \\
\hline One should adopt from competitors new ways of doing business. & .162 & .080 & 2 & 4.077 . & \\
\hline One should try new lines of products or service & -.161 & .110 & 3 & 2.141 . & \\
\hline One should try many new lines of product services & .222 & .123 & 2 & 3.238 . & \\
\hline typically responds to actions that competitors initiate & .173 & .078 & 2 & 4.892 . & \\
\hline $\begin{array}{l}\text { is seldom the first business to introduce new product/services, administrative } \\
\text { techniques, operating technologies etc. }\end{array}$ & -.169 & .106 & 2 & 2.567 . & \\
\hline $\begin{array}{l}\text { is very often the first business to introduce new product/services, administrative } \\
\text { techniques, operating technologies }\end{array}$ & .215 & .073 & 2 & 8.678 . & \\
\hline $\begin{array}{l}\text { is the one with strong tendency to follow the leader in introducing new product or } \\
\text { ideas. }\end{array}$ & .063 & .126 & 3 & .251. & \\
\hline $\begin{array}{l}\text { It is important to have a strong proclivity for low-risk projects (with normal and } \\
\text { certain rates of return) }\end{array}$ & .070 & .126 & 2 & .312 & \\
\hline $\begin{array}{l}\text { It is important to have a strong proclivity for high-risk projects (with chances of } \\
\text { very high returns). }\end{array}$ & .243 & .138 & 2 & 3.167. & \\
\hline It is unimportant to have a strong proclivity for low-risk projects & -.034 & .110 & 1 & 097 & \\
\hline It is unimportant to have a strong proclivity for high risk projects & -.035 & .131 & 2 & .070 & \\
\hline
\end{tabular}

Table 4 shows the regression coefficients indicating the significance of entrepreneurial orientation variables to business performance.

With regard to "my business profit", some of the variables (from entrepreneurial orientation) are above 0.050 level of significance and can therefore be regarded as weak predictors of business performance but only six; (is very often the first business to introduce new"; one should try new ways of doing things; one should try new ways of doing things; one should try many new lines of product services; typically responds to actions that competitors initiate; it is important to have a strong proclivity for high-risk projects), are predictors of business performance under "my business profit" with significance level of $0.000 ; 0.018 ; 0.013 ; 0.008 ; 0.000$ and 0.043 . Hypothesis $\left(H_{0} 1 b\right)$ is accepted for these variables.

The table shows some entrepreneurial orientation factor between $5 \%$ and $20 \%$ level of significance. Statistically, these factor (namely; is seldom the first business to introduce new; one should try new lines of products or service) can be considered as of marginal significance. These factors can be tested further in another research project. 


\subsection{My market share}

There is a significant positive relationship exists between entrepreneurial orientation and business performance $\left(\mathrm{H}_{0} 1 \mathrm{a}\right.$ : my market share).

With regard to "my market share" some variables affect business performance. The significance level of most variables falls above the $0.05 \%$ level of significance. They are not strong predictors of business performance.

Table 5: ANOVA: my market share

\begin{tabular}{|l|l|l|l|l|l|}
\hline & Sum of Squares & Df & Mean Square & F & Sig. \\
\hline Regression & 57.237 & 26 & 2.201 & 2.383 & .000 \\
Residual & 365.763 & 396 & .924 & & \\
Total & 423.000 & 422 & & & \\
\hline
\end{tabular}

The results from the analysis of variance are depicted in table 5 above. These show that the model variance (2.201) is considerably higher than the error variance $(0.924)$, indicating that the different predictors separately and conjointly succeeded in predicting business performance significantly at $95 \%$ level of certainty.

With regard to "my market share", some variables are above 0.050 level of significance and can therefore be regarded as weak predictors of business performance.

Table 6: Regression coefficients indicating the significance of entrepreneurial orientation variables to business performance.

\section{Coefficients}

\begin{tabular}{|c|c|c|c|c|c|}
\hline & \multicolumn{2}{|c|}{ Standardized Coefficients } & \multirow[b]{2}{*}{ Df } & \multirow[b]{2}{*}{$\mathrm{F}$} & \multirow[b]{2}{*}{ Sig. } \\
\hline & Beta & $\begin{array}{c}\text { Bootstrap (1000) } \\
\text { Estimate of Std. Error }\end{array}$ & & & \\
\hline One should try new ways of doing things. & .165 & .078 & & 4.414 & .013 \\
\hline One should adopt from competitors new ways of doing business. & -.026 & .128 & 1 & .042 & \\
\hline One should try new lines of products or service & .188 & .092 & & 4.212 & .00 \\
\hline One should try many new lines of product services & -.189 & .079 & & 5.811 & .003 \\
\hline typically responds to actions that competitors initiate & .179 & .177 & & 1.025 & 36 \\
\hline $\begin{array}{l}\text { is seldom the first business to introduce new product/services, administrative } \\
\text { techniques, operating technologies etc. }\end{array}$ & -.069 & .140 & 2 & .246 & \\
\hline $\begin{array}{l}\text { is very often the first business to introduce new product/services, administrative } \\
\text { techniques, operating technologies }\end{array}$ & .188 & .123 & & 5.811 & \\
\hline is the one with strong tendency to follow the leader in introducing new product or ideas. & -.150 & .153 & 1 & .961 & 328 \\
\hline $\begin{array}{l}\text { It is important to have a strong proclivity for low-risk projects (with normal and certain } \\
\text { rates of return) }\end{array}$ & -.100 & .091 & & 1.212 & .30 \\
\hline $\begin{array}{l}\text { It is important to have a strong proclivity for high-risk projects (with chances of very } \\
\text { high returns). }\end{array}$ & -.208 & .186 & & 1.244 & 29 \\
\hline It is unimportant to have a strong proclivity for low-risk projects & .120 & .118 & & 1.047 & 352 \\
\hline It is unimportant to have a strong proclivity for high risk projects & -.066 & .142 & & .215 & \\
\hline
\end{tabular}

Table 6 above shows the regression coefficients indicating the significance of entrepreneurial orientation variables to business performance.

With regard to "my market share", most variables are above 0.050 level of significance and cannot be regarded as predictors of business performance but only four (one should try new ways of doing things; one should try new lines of products or service; one should try many new lines of product services and is very often the first business to introduce new product/services, administrative techniques, operating technologies), are regarded as predictors of business performance with significance level of $0.013 ; 0.006 ; 0.003$ and 0.003 respectively. These variables are strong predictors of market share under business performance. Hypothesis $\left(\mathrm{H}_{0} 1 \mathrm{c}\right)$ is accepted for these variables. Negative factors will be tested again in another project. 


\subsection{My return on investment}

There is a significant positive relationship exists between entrepreneurial orientation and business performance $\left(\mathrm{H}_{0} 1 \mathrm{a}\right.$ : my return on investment).

With regard to "my return on investment" some variables affect business performance. The significance level of some of the variables falls above the $0.05 \%$ level of significance. There are few predictors of business performance.

Table 7: ANOVA: my return on investment

\begin{tabular}{|c|c|c|c|c|c|}
\hline & Sum of Squares & Df & Mean Square & F & Sig. \\
\hline Regression & 46.447 & 24 & 1.935 & 2.049 & .003 \\
Residual & 364.553 & 386 & .944 & & \\
Total & 411.000 & 410 & & & \\
\hline
\end{tabular}

The results from the analysis of variance are depicted in table 7 above. These show that the model variance (1.935) is considerably higher than the error variance (0.944), indicating that the different predictors separately and conjointly succeeded in predicting business performance significantly at $95 \%$ level of certainty.

With regard to "my return on investment", the majority of variables are above 0.050 level of significance and can therefore be regarded as weak predictors of business performance.

Table 8: Regression coefficients indicating the significance of entrepreneurial orientation variables to business performance.

\section{Coefficients}

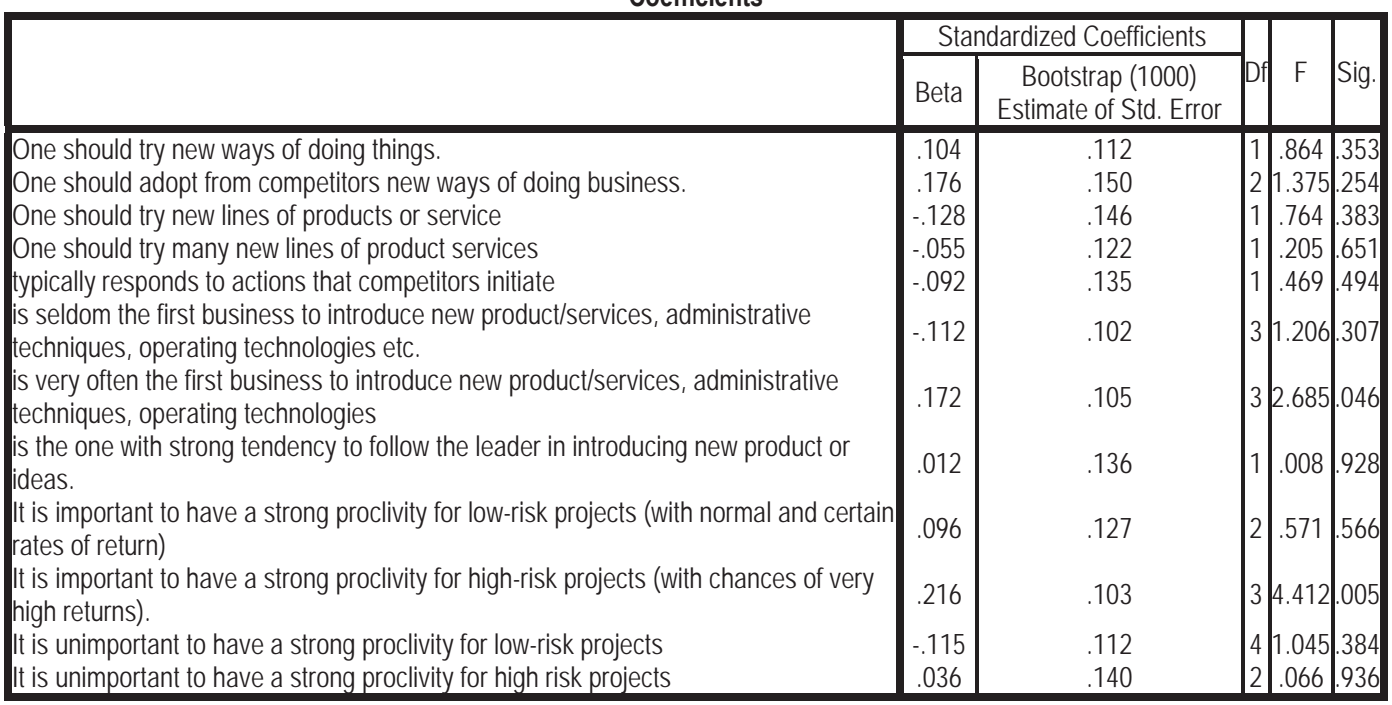

With regard to "my return on investment", the majority of variables (from entrepreneurial orientation) are above 0.050 level of significance and can therefore be regarded as weak predictors of business performance but only two (It is important to have a strong proclivity for high-risk projects (with chances of very high returns); is very often the first business to introduce new product/services,), are predictor of business performance with significance level of 0.005 and 0.046 respectively. Hypothesis $\left(\mathrm{H}_{0} 1 \mathrm{~d}\right)$ is accepted on these variables only and rejected on variables that are negative. Further test on weak predictors will be done in another study.

\subsection{Number of employees}

There is a significant positive relationship exists between entrepreneurial orientation and business performance $\left(\mathrm{H}_{0} 1 \mathrm{e}\right.$ : 
number of employees).

With regard to "number of employees" some variables (from entrepreneurial orientation) affect business performance. The significance level of all the variables falls above the $0.05 \%$ level of significance. There are few strong predictors of business performance.

Table 9: ANOVA: number of employees

\begin{tabular}{|c|c|c|c|c|c|}
\hline & Sum of Squares & Df & Mean Square & $\mathrm{F}$ & Sig. \\
\hline Regression & 54.841 & 26 & 2.109 & 2.268 & .000 \\
Residual & 371.159 & 399 & .930 & & \\
Total & 426.000 & 425 & & & \\
\hline
\end{tabular}

The results from the analysis of variance are depicted in table 9 above. These show that the model variance (2.109) is considerably higher than the error variance $(0.930)$, indicating that the different predictors separately and conjointly succeeded in predicting business performance significantly at $95 \%$ level of certainty.

With regard to "number of employees", the majority of variables are above 0.050 level of significance and can therefore be regarded as weak predictors of business performance.

Table 10: Regression coefficients indicating the significance of entrepreneurial orientation variables to business performance

\begin{tabular}{|c|c|c|c|c|c|}
\hline \multicolumn{6}{|l|}{ Coefficients } \\
\hline & \multicolumn{2}{|c|}{ Standardized Coefficients } & \multirow{2}{*}{\multicolumn{2}{|c|}{ Df $F$}} & \multirow[b]{2}{*}{ Sig. } \\
\hline & Beta & $\begin{array}{c}\text { Bootstrap (1000) } \\
\text { Estimate of Std. Error }\end{array}$ & & & \\
\hline One should try new ways of doing things. & .222 & .123 & & 3.238 & 3.013 \\
\hline One should adopt from competitors new ways of doing business. & -109 & .122 & 2 & .808 & 447 \\
\hline One should try new lines of products or service & -.215 & .079 & & 7.377 & .000 \\
\hline One should try many new lines of product services & .207 & .098 & & 4.480 & .018 \\
\hline typically responds to actions that competitors initiate & .165 & .078 & & 4.414 & .013 \\
\hline $\begin{array}{l}\text { is seldom the first business to introduce new product/services, administrative } \\
\text { techniques, operating technologies etc. }\end{array}$ & .030 & .143 & 1 & .045 & .833 \\
\hline $\begin{array}{l}\text { is very often the first business to introduce new product/services, administrative } \\
\text { techniques, operating technologies }\end{array}$ & .186 & .082 & & 5.087 & .002 \\
\hline $\begin{array}{l}\text { is the one with strong tendency to follow the leader in introducing new product or } \\
\text { ideas. }\end{array}$ & .134 & .104 & & 1.673 & .172 \\
\hline $\begin{array}{l}\text { It is important to have a strong proclivity for low-risk projects (with normal and certain } \\
\text { rates of return) }\end{array}$ & -.184 & .113 & & 2.641 & .049 \\
\hline $\begin{array}{l}\text { It is important to have a strong proclivity for high-risk projects (with chances of very } \\
\text { high returns). }\end{array}$ & .107 & .099 & & 1.165 & 313 \\
\hline It is unimportant to have a strong proclivity for low-risk projects & -.034 & .100 & 3 & .119 & .949 \\
\hline It is unimportant to have a strong proclivity for high risk projects & -.024 & .118 & & .041 & .840 \\
\hline
\end{tabular}

With regard to "number of employees", some of the variables are above 0.050 level of significance and can therefore be regarded as weak predictors of business performance but at least six (one should try new ways of doing things; typically responds to actions that competitors initiate; one should try many new lines of products or service; one should try new lines of products or service; is very often the first business to introduce new product/services); it is important to have a strong proclivity for low-risk projects (with normal and certain rates of return), are predictors of business performance under "number of employees" with significance level of $0.000 ; 0.018 ; 0.013 ; 0.013 ; 0.002$ and 0.049 respectively. Hypothesis $\left(\mathrm{H}_{0} 1 \mathrm{e}\right)$ is accepted with these variables. Negative variable are rejected and will need further tests in another study.

\subsection{Product lines}

There is a significant positive relationship exists between entrepreneurial orientation and business performance $\left(\mathrm{H}_{0} 1 \mathrm{f}\right.$ : 
product lines).

With regard to "product lines" some variables (from entrepreneurial orientation) affect business performance. The significance level of most of the variables falls above the $0.05 \%$ level of significance. They are not strong predictors of business performance.

Table 11: ANOVA: product lines

\begin{tabular}{|c|c|c|c|c|c|}
\hline & Sum of Squares & Df & Mean Square & $F$ & Sig. \\
\hline Regression & 71.565 & 25 & 2.863 & 3.231 & .000 \\
Residual & 354.435 & 400 & .886 & & \\
Total & 426.000 & 425 & & & \\
\hline
\end{tabular}

The results from the analysis of variance are depicted in table 11 above. These show that the model variance (2.863) is considerably higher than the error variance $(0.886)$, indicating that the different predictors separately and conjointly succeeded in predicting business performance significantly at $95 \%$ level of certainty.

With regard to "product lines", some of the variables are above 0.050 level of significance and can therefore be regarded as weak predictors of business performance.

Table 12: Regression coefficients indicating the significance entrepreneurial orientation variables to business performance

\section{Coefficients}

\begin{tabular}{|c|c|c|c|c|c|}
\hline & \multicolumn{2}{|c|}{ Standardized Coefficients } & \multirow[b]{2}{*}{ Df } & \multirow[b]{2}{*}{$\mathrm{F}$} & \multirow[b]{2}{*}{ Sig. } \\
\hline & Beta & $\begin{array}{l}\text { Bootstrap (1000) } \\
\text { Estimate of Std. Error }\end{array}$ & & & \\
\hline One should try new ways of doing things. & .098 & .060 & & 2.614 & \\
\hline One should adopt from competitors new ways of doing business. & -.134 & .091 & & 2.176 & 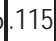 \\
\hline One should try new lines of products or service & -.184 & .113 & & 2.641 & .049 \\
\hline One should try many new lines of product services & .212 & .076 & & 7.785 & \\
\hline typically responds to actions that competitors initiate & .207 & .098 & & 4.480 & \\
\hline $\begin{array}{l}\text { is seldom the first business to introduce new product/services, administrative } \\
\text { techniques, operating technologies etc. }\end{array}$ & .011 & .114 & 1 & .010 & \\
\hline $\begin{array}{l}\text { is very often the first business to introduce new product/services, administrative } \\
\text { techniques, operating technologies }\end{array}$ & .186 & .085 & & 4.718 & \\
\hline is the one with strong tendency to follow the leader in introducing new product or ideas. & -.016 & .130 & 2 & .014 & \\
\hline $\begin{array}{l}\text { It is important to have a strong proclivity for low-risk projects (with normal and certain } \\
\text { rates of return) }\end{array}$ & .162 & .080 & & 4.077 & \\
\hline $\begin{array}{l}\text { It is important to have a strong proclivity for high-risk projects (with chances of very } \\
\text { high returns). }\end{array}$ & .147 & .064 & & 5.33 & \\
\hline It is unimportant to have a strong proclivity for low-risk projects & -.135 & .097 & & 1.940 & \\
\hline It is unimportant to have a strong proclivity for high risk projects & .074 & .117 & & .402 & \\
\hline
\end{tabular}

With regard to "product lines", some variables (entrepreneurial orientation) are above 0.050 level of significance and can therefore be regarded as weak predictors of business performance but only six (one should try many new lines of product services; is very often the first business to introduce new product/services, administrative techniques, operating technologies; one should try new lines of products or service; it is important to have a strong proclivity for low-risk projects; typically responds to actions that competitors initiate; it is important to have a strong proclivity for high-risk projects), are predictor of business performance under "product line" with significance level of $0.049 ; 0.004 ; 0.000 ; 0.018$; 0.009 and 0.001 respectively. Hypothesis $\left(\mathrm{H}_{0} 1 \mathrm{f}\right)$ is accepted with these variables and rejected with weak predictors of business performance factors.

These findings, depicting the magnitude of the business environment in the study area, clearly confirm the positive impact of entrepreneurial orientation on business performance. This conclusion enlightens the first research question, namely, the possible positive impacts of entrepreneurial orientation on business performance. The variables relating to this phenomenon are best predictors of business performance. The strong predictive value of entrepreneurial orientation as independent variables of business performance confirms that these factors should be there in individual entrepreneur 
for the business to perform better. It is clear from the tables above that other variables do not impact the business performance at all.

\section{Conclusion and Recommendations}

As indicated above, some of entrepreneurial orientation factors are not predictors of business performance. The following were found to be predictors of business performance: is very often the first business to introduce new product; one should try many new lines of product services; is very often the first business to introduce new product/services, administrative techniques, operating technologies; one should try new lines of products or service; it is important to have a strong proclivity for low-risk projects (with normal and certain rates of return); typically responds to actions that competitors initiate; it is important to have a strong proclivity for high-risk projects (with chances of very high returns)"and one should try new lines of products or service. The rest of the factors were found to be weak predictors of business performance. Therefore they should be taken out of the factors that predict business performance. The study done by Radipere (2013) finds that there is a significant correlation between entrepreneurial orientation and business performance. This result confirms Wiklund and Shepherd's (2005:90) finding that entrepreneurial orientation leads to higher performance and that businesses that adopt a strong entrepreneurial orientation perform better than ones that do not. The findings of this article suggest that entrepreneurial orientation (proactiveness, innovativeness and risk taking) positively influence small business performance. Entrepreneurial orientation is not a luxury of firms in high growth industries with abundant financial capital but entrepreneurial orientation can be used to overcome environmental and resource constraints. Firms in these situations can be superior performers if they have a high entrepreneurial orientation (Wiklund \& Shepherd, 2005). Entrepreneurial orientation provides the business with the ability to find or discover new opportunities that can differentiate them from other firms and create a competitive advantage.

The level of significance of the 8 out of 12 independent variables suggests that entrepreneurial orientation be classified as the strongest predictor of business performance.

The study suggest that scholars may need to pay greater attention to both joint and interdependent effects of performance predictors rather than a reliance solely on main effects or two-way interactions. By using entrepreneurial orientation, managers can benefit from being innovative and proactive and from pursuing risky new initiatives, thus differentiating their firms from competitors.

\section{Limitation and Future Research}

Due to localised nature of the study in Gauteng province (South Africa) as well as small sample size involved, the findings of this study cannot be generalised. This becomes a major limitation when the small sample in Gauteng province only is considered against the fact that there are more than 10000 SMMEs in the country. It is suggested that future studies could perhaps use sample from all nine provinces in South Africa to present an overall picture of SMMEs.

\section{References}

Andendorff, C.M. 2004. The development of a cultural family business model of good governance for Greek family business in South Africa. Doctoral thesis in Business Management, Rhodes University, Grahamstown.

Antonic, B \& Hisrich, R.D. 2003. Clarifying the intrapreneurship concept. Journal of Small Business and Enterprise Development, 10 (1): 7-24.

Bandura. A. 1997. Self-efficacy. The exercise of control. New York: Freeman \& Co.

Cooper, A.C \& Gascon, E.J.G.1992. Entrepreneurs, processes of founding, and new-firm performance, in The state of art of entrepreneurship, edited by DL Sexton \& JD Kassadra. Boston: PWS-Kent.

Cooper, D.R \& Schindler, P.S. 2008. Business research methods. 10 ${ }^{\text {th }}$ edition. Boston: McGraw-Hill Irwin.

Global Entrepreneurship Monitor (GEM).2011. 2011 Report on Higher Expectation Entrepreneurship from:www.gemconsortium.org (accessed on 1 June 2011).

Global Entrepreneurship Monitor (GEM) 2012. 2012 Report on Higher Expectation Entrepreneurship from: www.gemconsortium.org (accessed 4 March 2014).

Li, Y.H, Huang, J.W \& Tsai, M.T. 2009. Entrepreneurial orientation and company performance: The role of knowledge creation process. Industrial Marketing Management 38(209):440-449.

Lumpkin, G.T \& Dess, G.G. 2001. Linking two dimensions of entrepreneurial orientation to business performance: The moderating role of environment and industry life cycle. Journal of Business Venturing 16:429-451.

Murphy, G.B., Trailer, J.W. \& Hill, R. 1996. Measuring performance in entrepreneurship research. Journal of Business Research. Vol. 36(1): pp15-23. 
Radipere, N.S. 2013. Analysis of local and immigrant entrepreneurship in the South African small enterprise sector (Gauteng province). D Com (Business Management) thesis, University of South Africa, Pretoria.

Rauch, A, Wiklund, J, Lumpkin, GT \& Frese, M. 2009. Entrepreneurial orientation and business performance: An assessment of past research and suggestions for the future. Entrepreneurship Theory and Practice 33(3):761-787.

Rwigema, H, Urban, B \& Venter, R. 2008. Entrepreneurship. Theory in practice. $2^{\text {nd }}$ edition. Cape Town: Oxford University Press.

Wiklund, J \& Shepherd, D. 2003. Knowledge-based resources, entrepreneurial orientation and performance of small and medium businesses. Strategic Management Journal 24:1307-1314.

Wiklund, J \& Shepherd, D. 2005. Entrepreneurial orientation and small business performance: A configurational approach. Journal of Business Venturing 20:71-91. 